\section{Visión Electrónica \\ Más que un estado sólido}

UNIVERSIDAD DISTRITAL

FRANCISCO JOSÉ DE CALDAS https://doi.org/10.14483/issn.2248-4728

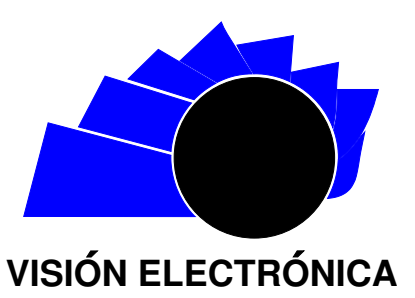

A RESEARCH VISION

\title{
Mechanical model of the extrinsic muscles of the eyeball
}

\author{
Modelo mecánico de los músculos extrínsecos del globo ocular
}

Jesica Liceth Talero-Maldonado ${ }^{(1)}{ }^{1}$, Ricardo Alonso Espinosa-Medina ${ }^{(\mathbb{D}} 2$

INFORMACIÓN DEL ARTÍCULO

Historia del artículo:

Enviado: 26/11/2019

Recibido: 09/12/2019

Aceptado: 06/01/2020

\section{Keywords:}

Extraocular muscles

Eye rotation

Mathematical model

Oculomotor system

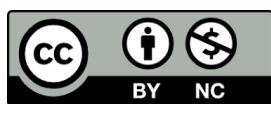

Palabras clave:

Músculos extraoculares

Rotación ocular

Modelo matemático

Sistema oculomotor

\begin{abstract}
Mathematical modelling of the physiological behaviour of extraocular muscles in eye rotation contributes to our understanding of the oculomotor system and the development of technologies for device control through the accurate prediction of the ocular displacement path. In this article, we propose a mechanical model of eye movement, which incorporates the physiological properties of extraocular muscles in the force-elongation relationship and the action of the agonist and antagonist muscles. An easy-to-understand model is presented, analyzing the forces applied in muscle contraction and the variation in extraocular muscle length, which cause the rotation of the eye and the vector interpretation of the direction in the space towards which the eye directs the view during movements of adduction, abduction, elevation and depression. The proposed model simplifies the mathematical description, compared with other models, in relation to the action of the mechanical elements (springs and dampers) that represent the anatomical and physiological components of the contractile mechanics of the extraocular muscles. The implementation of the proposed model could assist the future development of technologies that emulate horizontal or vertical eye movements for the control of devices.
\end{abstract}

\section{RESUMEN}

El modelamiento matemático del comportamiento fisiológico de los músculos extraoculares en la rotación ocular, contribuye en el aprendizaje del sistema oculomotor y en el desarrollo de tecnologías para el control de dispositivos, a través de la predicción precisa de la trayectoria de desplazamiento ocular. Nosotros proponemos en el presente artículo un modelo mecánico del movimiento ocular, que incorpora las propiedades fisiológicas de los músculos extraoculares en la relación de fuerza-elongación y la acción de los músculos agonistas y antagonistas. Se presenta un modelo de fácil comprensión que permite el análisis de fuerzas aplicadas en la contracción muscular, la variación de longitud del musculo extraocular, que genera rotación del ojo y la interpretación vectorial de la dirección en el espacio hacia donde el ojo dirige la vista en movimientos de aducción, abducción, elevación y depresión. El modelo propuesto permite una simplificación de la descripción matemática, frente a otros modelos, de la acción de los elementos mecánicos (resortes y amortiguadores) que representan los componentes anatómicos y fisiológicos de los músculos extraoculares. La implementación del modelo propuesto podría servir a futuro en el desarrollo de tecnologías que emulen movimientos oculares horizontales u verticales para el control de dispositivos.

${ }^{1}$ BSc. (c) in Biomedical Engineering, Universidad ECCI, Colombia. Member of the Research Seedbed in Biomedical Applications-EMB-IEEE. E-mail: jesical.talerom@ecci.edu.co

${ }^{2}$ BSc. in Biomedical Engineering, Universidad Manuela Beltrán, Colombia. Specialist in Bioengineering, Universidad Distrital Francisco José de Caldas, Colombia. MSc. in Biomedical engineering, Universidad Nacional de Entre Ríos, Argentina. Leader of the Research Seedbed in Biomedical Applications-EMB-IEEE. Current position: Universidad ECCI, Colombia. E-mail: respinosam@ecci.edu.co

Cite this article as: J. L. Talero-Maldonado and R. A. Espinosa-Medina, "Mechanical model of extrinsic muscles of the eyeball", Visión electrónica, vol. 14, no. 1, pp. 19-25, january 2020. https://doi.org/10. 14483/22484728. 15905 


\section{Introduction}

Mathematical models related to the prediction of eye movements are used to improve our understanding of the oculomotor system and are applied in the development of bioinspired technologies. Hoerantner and Kaltofen (2007) used mathematical models to create simulators that analyzed the action of the oblique and rectus muscles in the eye to help plan treatments for the correction of strabismus and high axial myopia [1].

In the development of bioinspired technologies, mathematical models are frequently used in the mechanical and electronic conditioning of security cameras, which simulate eye movements in the vision scanning function.

The mathematical model of eye movement considers the biomechanical action of the extraocular muscles: rectus superior, inferior, medial and lateral. Bahill (1980) introduced Hill's muscular model (skeletal muscle represented as a mechanical system) into the mathematical model of eye movements and defined the values of the passive elements that make up the mechanical system [2]. The oculomotor plant mathematical model, proposed by Holland and Komogorstev in 2013, describes the characteristics of the eye and the extraocular muscles responsible for vertical and horizontal eye movement [3]. The two models are similar and make use of the state matrix to incorporate the necessary variables that result in vertical and horizontal eye movements. The mathematical analysis of these models can be complex, which can limit their application in the real world.

In this study, we propose a mathematical model of eye movement using an alternative to the classic Hill model, which considers the anatomical properties of extraocular muscles and simplifies the equations that govern the variables involved in the physiological process of muscle activation, resulting in eye movements in different directions.

\section{Methodology}

\subsection{Structural representation of the extrinsic muscles of the eyeball}

The eyeball is considered a solid spherical structure, to which the extraocular muscles (superior, inferior, medial and lateral rectus) are anatomically inserted, which allows the eye limited horizontal and vertical rotations in the orbital cavity.
The representation of the eye in primary position can be seen in Figure 1, which reflects the eye looking straight ahead.

Figure 1: Extraocular rectus muscles of the human eye.

\section{Superior rectus}

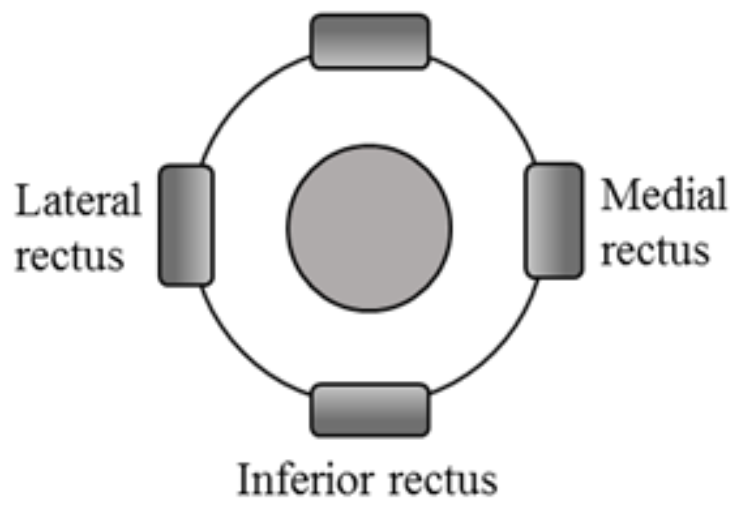

Source: own

The dimensions of the oculomotor system components are also a source of information for the mathematical model proposed in this work. The following anatomical dimensions of the eye according to [4] were taken into account: eyeball (radius: $0.012 \mathrm{~m}$ ), cornea (radius: vertically $0.005 \mathrm{~m}$; horizontally $0.006 \mathrm{~m}$ ) and pupil (radius: 0.0015-0.00225 m). The lengths of the extraocular recti according to [5] were also taken into account: medial rectus muscle (length: $0.041 \mathrm{~m}$ ), lateral rectus muscle (length: $0.041 \mathrm{~m}$ ), superior rectus muscle (length: $0.042 \mathrm{~m}$ ) and inferior rectus muscle (length: $0.042 \mathrm{~m})$.

Figure 2 shows the eye movements considered in this study according to the muscular behaviour of the four extraocular recti. The eye movement was considered to start from the primary position (Figure 1 ), changing to the secondary position of the gaze and then in a rotation (depression: movement of the pupil downward, elevation: movement of the pupil upward, abduction: movement of the pupil in the lateral direction outward and adduction: movement of the pupil inward or in the nasal direction).

To represent the mechanical action of extraocular muscles, the physiological model of the muscle reported by [6], which is a variation of the mechanical system in the classic Hill model, was used to determine the relationship of strength vs. elongation. Figure 3 shows the muscle model used, which incorporates the same elements and is interpretively similar to the Hill muscle model, but in a different configuration. 
Figure 2: Eye movement: A. depression, B. elevation, C. abduction and D. adduction.
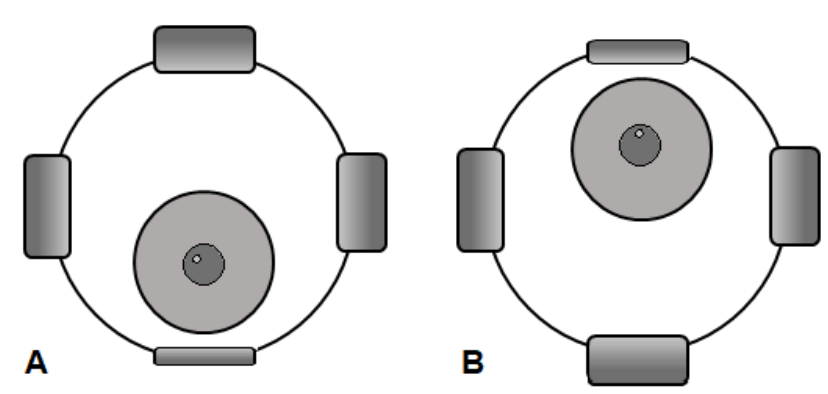

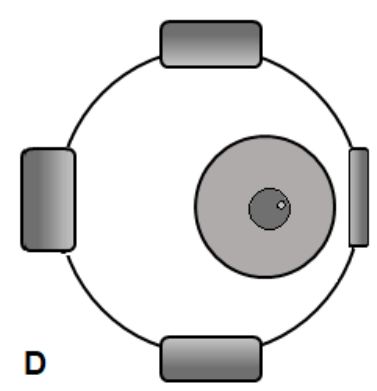

Source: own

The movement of the eye in one direction (vertically or horizontally) basically depends on two muscles: the contraction of a muscle that acts as an agonist or collaborator in the execution of the movement and the relaxation of a muscle that acts as an antagonist of the movement.

The muscle model used in this work represents the behaviour of a voluntary contraction muscle and relates to the real force that occurs in the muscle $(F)$, taking into account its mechanical properties, and the value of the maximum contractile force corresponds to $100 \mathrm{gt}$ (equivalent to $0.98 \mathrm{~N}$ ). $F_{O}$ is the force developed by the active contractile element of the muscle, which physiologically corresponds to the myofibrils and sarcomeres of the extraocular muscle. $F o$ can be considered a percentage of the maximum force according to [7]. In this study, Fo is equal to $0.26 \%$ of $F$.

The series elastic element $(\mathrm{Ce})$ represents the elasticity of the cross actin-myosin junction of the striated fibres and the elastic behaviour of the tendons inserted in the anterior part of the sclera, with a value of $2.5 \mathrm{gt} /{ }^{\circ}$ [2] (equivalent to $125 \mathrm{~N} / \mathrm{m}$ ), whereas the parallel elastic element $(C p)$ describes the elastic properties of the sarcolemma of the extraocular muscles, with a value of $0.5 \mathrm{gt} /{ }^{\circ}(25 \mathrm{~N} / \mathrm{m}) . \mathrm{R}$ is the viscous damping present in the connective tissue of the eye, equal to 0.06 gt-s $/{ }^{\circ}$ [2] (equivalent to $3.1 \mathrm{Ns} / \mathrm{m}$ ).

In this study, the eye rotations performed under the response of the four extraocular lines were considered: in horizontal movements (adduction and abduction), by the mechanical action of the medial and lateral recti; in main vertical movements (elevation and depression), by the mechanical action of the superior and inferior recti.

In Figure 3, the representative linear mechanical model of the physiological behaviour of the extraocular rectus muscles is observed during ocular rotation.
Figure 3: Linear model of muscular mechanics.

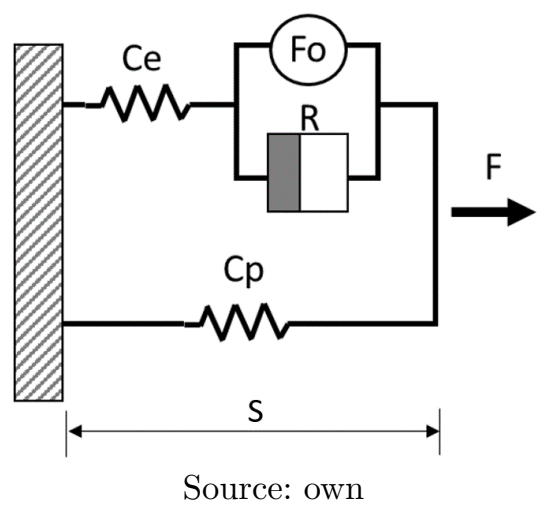

The resulting differential equation of the mechanical system in Figure 3 is described in (1) and represents the behaviour of the muscle action when contracted voluntarily. When a force $F$ is applied at the entrance of the mechanical system, it varies the length of the muscle $\mathrm{S}$, which provides the system output.

$$
\frac{d F}{d t}+\frac{1}{R C e} F=\left(\frac{1}{C e}+\frac{1}{C p}\right) \frac{d S}{d t}+\frac{1}{R C e C p} S+\frac{F o}{R C e}
$$

Laplace transform was applied to the differential equation (1) to find the variable $S(s)$, which corresponds specifically to the shortening length of the agonist muscle during contraction, acting as an effector by pulling the eyeball in the required direction. At the same time, the antagonist muscle proportionally stretches the same length $S$, calculated by (2) and representing a relaxing action.

$$
S(s)=\frac{\frac{F(s)}{R C e}+s F(s)-\frac{F o(s)}{R C e}}{\frac{1}{R C e C p}+\left(\frac{1}{C e}+\frac{1}{C p}\right) s}
$$

The dynamic balance of the extrinsic eyeball muscles allows the eye to maintain a primary gaze position, with 
a forward vision. An illustrated example of the action of the superior and inferior rectus muscles is presented in Figure 4A.

The depression movement is shown in Figure 4B, which illustrates the contraction of the agonist muscle (for this example, the inferior rectus muscle). The muscle contracts a distance $S$, and the antagonist (superior rectus) relaxes. The action of the eyeball mass is considered void because the mechanical system does not drag the mass; it only rotates it at certain angles, which are, on average, of a low value. In addition, the mass is held by the four rectus muscles, which implies a weight distribution.

If we consider the eyeball, seen from the sagittal plane, as a circumference, we can say that the rotation of the eye is caused by the drag of the muscle when contracting a distance S, without distorting the eyeball.

Figure 4: A. Outline of the eye in dynamic equilibrium (primary position). B. Outline of the eye during eye movement.

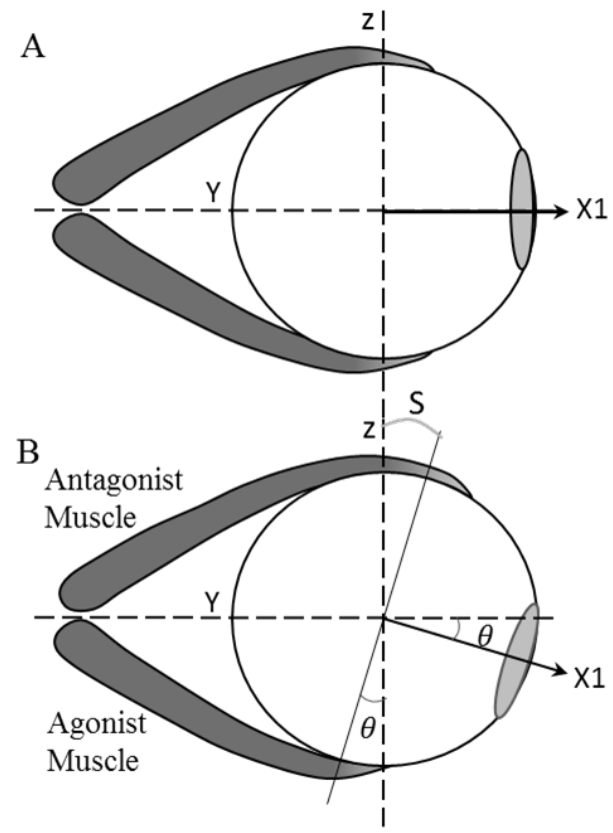

Source: own

Therefore, there is a relationship between $\mathrm{S}$ (seen as the arc of the circumference) and the angle that indicates the rotation of the eye with respect to the main axis of equilibrium (see Figure 4B).

The arc length $S$ is calculated using the inverse Laplace transform of equation (2). $R$ is the radius of the eyeball, equal to $0.012 \mathrm{~m}$ (ideally considering the eyeball as a perfect circumference). The angle $\theta$ can be calculated using equation (3):

$$
\theta=\frac{S * 180^{\circ}}{\pi * R}
$$

The above applies equally for the action of both lateral rectus muscles (medial and lateral) in horizontal rotation movements.

The angle $\theta$ obtained by the action of the superior and inferior rectus muscles is called the elevation angle. The angle $\alpha$ obtained by the action of the lateral and medial rectus muscles is called the horizontal scan angle. The conversion of spherical coordinates to Cartesian coordinates can be performed using equations (4-6):

$$
\begin{gathered}
X=r * \cos (\theta) * \cos (\alpha) \\
Y=r * \cos (\theta) * \sin (\alpha) \\
Z=r * \cos (\theta)
\end{gathered}
$$

Figure 5 shows the three-dimensional plane $(X, Y, Z)$ of the eyeball during the execution of a movement and the direction of orientation of the view represented by the vector X1. In horizontal and vertical path movements, one of the three-dimensional axes that is common for eye movements is shared.

Figure 5: Three-dimensional plane in eye movement.

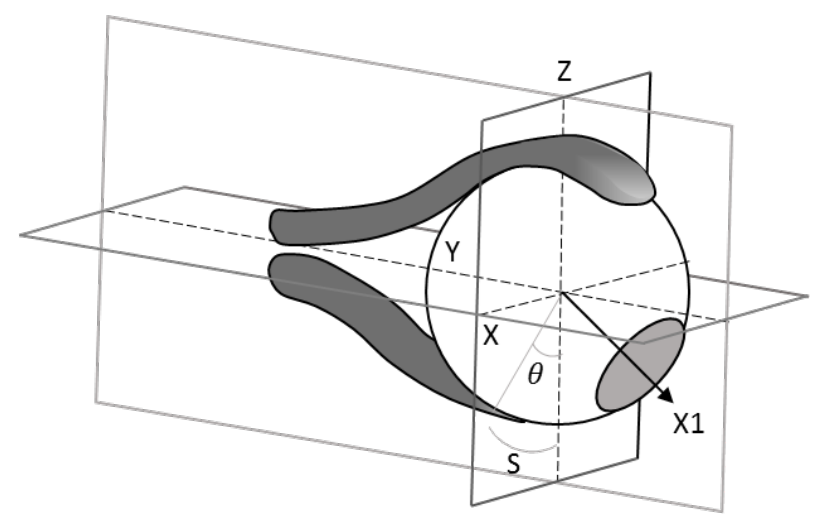

Source: own

The superior and inferior rectus muscles allow the pupil to move up and down (coordinates in the $Y$ and $Z$ axes), and the lateral muscles allow the pupil to move to the right and left (coordinates in the $X$ and $Y$ axes). 


\section{Results}

In the developed model, the mechanical behaviour of the superior-inferior and lateral-medial rectus muscles was considered. The application of the mathematical model, taking into account the mechanical properties of the extraocular muscles, allowed us to vary the force at the entrance of the system, which enabled a change in the length of the extraocular muscle at the output of the system. This acted as an effector of the movement or agonist while the antagonist was elongated.

For vertical rotation, in the case of elevation movement, the maximum angle in the vertical upward direction was $42^{\circ}$ (range: $33^{\circ}$ to $56^{\circ}$ ) [8], and for the depression movement, the maximum angle of the ocular rotation to direct the view downwards was $50^{\circ}$ (range: $33^{\circ}$ to $62^{\circ}$ ). The values obtained for angle, applied force, length of contraction, stretching and maximum force ranges can be seen in Table 1 .

Table 1: Results obtained after the application of the mechanical model in vertical rotation.

\begin{tabular}{|c|c|c|c|c|c|}
\hline $\begin{array}{l}\text { Movement } \\
\text { Vertical rotation }\end{array}$ & Angle & Strength & $\begin{array}{l}\text { Final length in } \\
\text { contraction }\end{array}$ & $\begin{array}{l}\text { Final stretch } \\
\text { length }\end{array}$ & $\begin{array}{l}\text { Maximum force } \\
\text { ranges applied }\end{array}$ \\
\hline $\begin{array}{c}\text { Movement } \\
\text { of elevation }\end{array}$ & $42^{\circ}$ & $0.47 \mathrm{~N}$ & $\begin{array}{l}0.0344 \mathrm{~m} \\
\text { Superior rectus }\end{array}$ & $\begin{array}{c}0.0475 \mathrm{~m} \\
\text { Inferior rectus }\end{array}$ & $0.37 \mathrm{~N}-0.63 \mathrm{~N}$ \\
\hline $\begin{array}{c}\text { Movement } \\
\text { of depression }\end{array}$ & $50^{\circ}$ & $0.56 \mathrm{~N}$ & $\begin{array}{c}0.031 \mathrm{~m} \\
\text { Inferior rectus }\end{array}$ & $\begin{array}{l}0.0509 \mathrm{~m} \\
\text { Superior } \\
\text { rectus }\end{array}$ & $0.37 \mathrm{~N}-0.70 \mathrm{~N}$ \\
\hline
\end{tabular}

Source: own

Table 2: Results obtained after the application of the mechanical model in horizontal rotation.

\begin{tabular}{|c|c|c|c|c|c|}
\hline $\begin{array}{c}\text { Movement Variable } \\
\text { Horizontal rotation }\end{array}$ & Angle & Strength & $\begin{array}{c}\text { Final length in } \\
\text { contraction }\end{array}$ & $\begin{array}{c}\text { Final stretch } \\
\text { length }\end{array}$ & $\begin{array}{c}\text { Maximum force } \\
\text { ranges applied }\end{array}$ \\
\hline $\begin{array}{c}\text { Movement } \\
\text { adduction }\end{array}$ & $55^{\circ}$ & $0.61 \mathrm{~N}$ & $\begin{array}{c}0.0311 \mathrm{~m} \\
\text { Medial rectus }\end{array}$ & $\begin{array}{c}0.0508 \mathrm{~m} \\
\text { Lateral rectus }\end{array}$ & $0.51 \mathrm{~N}-0.73 \mathrm{~N}$. \\
\hline $\begin{array}{c}\text { Movement } \\
\text { abduction }\end{array}$ & $55^{\circ}$ & $0.62 \mathrm{~N}$ & $\begin{array}{c}0.031 \mathrm{~m} \\
\text { Lateral rectus }\end{array}$ & $\begin{array}{c}0.0508 \mathrm{~m} \\
\text { Medial rectus }\end{array}$ & $0.51 \mathrm{~N}-0.73 \mathrm{~N}$ \\
\hline
\end{tabular}

Source: own

In horizontal rotation, the maximum angle in the lateral direction for adduction and abduction was approximately $55^{\circ}$ (range: $45^{\circ}$ to $65^{\circ}$ ) [8]. To effect an adduction movement, in which the eye rotates towards the nose, the medial rectus contracted, and the lateral rectus stretched. The values obtained for angle, applied force, contraction length, stretching and maximum force ranges can be seen in Table 2 .

The analysis of the coordinated movements allowed us to identify that if both eyes moved in the same direction, while there is an adduction movement caused by the action of the agonist muscle (medial rectus) in the left eye, the medial rectus acts as an antagonist and generates an abduction movement simultaneously in the right eye.

The interpretation of the model and the results obtained (in the ranges of maximum force required to perform movements in the normal way) allowed us to theoretically compare the mechanical effects in cases of muscular weakness, since coordination deficiencies are 
apparent during the execution of an ocular rotation, as in the case of strabismus.

\section{Discussion}

During an ocular rotation, starting from the primary position, the movement path can be identified by the movement of the pupil, which is due to the action of four extrinsic muscles (the superior, inferior, medial and lateral rectus). These actions create movements of adduction, abduction, elevation and depression. Such movements generate angle changes with respect to the main axis, which, by compensation, correspond to the angle formed between the shortening distance of the agonist muscle with respect to the main axis $\mathrm{X} 1$.

The proposed model allowed us to identify the relationship between the application of force in a mechanical system (representing the physiological behaviour in response to muscular activation), the analysis of the lateral and medial rectus muscle action in horizontal rotation and the action of superior and inferior rectus muscles in vertical rotation. Understanding the maximum force ranges required to perform an eyeball movement may be useful in the medical field for the detection or future treatment of strabismus, in which muscle control is poor and, therefore, the eyes do not align in the same direction.

The model proposed in this work is simple and easy to understand and implement because it incorporates variables from other traditional models, such as the muscle dynamics proposed by Hill (non-linear relationship of force-elongation) and from the Bahill model, which include variables such as viscous damping and elastic elements in series and in parallel. Therefore, the proposed mechanical model can be applied in the control of devices through the prediction of oculomotor system behaviour and the development of technology that emulates ocular movement or performs ocular tracking to operate systems.

\section{Conclusions}

Activation of the agonist and antagonist extraocular muscles generates a dynamic equilibrium position change of the eye because of their mechanical action, resulting in ocular movements of elevation, depression, adduction or abduction.

The physiological behaviour of the extraocular muscles was interpreted through a mechanical model that incorporates the viscosity of the connective tissue of the eye (represented in the model as a damping) and the elastic elements present in the muscular system of the eye (represented as series and parallel springs in the model).

Extraocular muscle activity generates a movement in the eyeball, modelled in this work as a sphere. The effect of only a pair of rectus muscles (superior-inferior or lateral-medial) was considered to calculate the angle formed between the main axis X1 and the equilibrium position using the relationship circumference arc and the radius of the eyeball. The rotation movements were analyzed in a coordinate system of the main axes (X, $\mathrm{Y}, \mathrm{Z})$, and the angles obtained were generated by the activity of the rectus muscles, which accurately represented the actual behaviour of eye movement. The strength of the extraocular muscle, which originated in the contractile element or sarcomeres, is modified by the mechanical process generated during an ocular rotation. This process influences properties such as tissue viscosity, generating friction and the elastic action of the tendons.

The proposed model allows simplified understanding of the oculomotor system, compared with other more complex models, and is useful in learning and interpreting the activity of extraocular muscles, through spherical coordinates and analysis in planes (X, Y, Z). The proposed mechanical model has possible application in the future development of eye-tracking technology that operates systems by predicting oculomotor behaviour using the maximum force ranges to simulate eye movement, as well as in the optimization of technologies that depend on or mimic eye movements and the effects of eyepieces pathologies.

\section{Acknowledgments}

Seedbed of Research in Biomedical Applications EMB-IEEE, ECCI University, Biomedical Engineering Program, Bogotá, Colombia.

\section{References}

[1] R. Hoerantner et al., "Model-based improvements in the treatment of patients with strabismus and axial high myopia", Invest. Ophthalmol. Vis. Sci., vol. 48, no. 3, pp. 1133-1136, Mar. 2007. https://doi.org/ 10.1167/iovs.06-0769

[2] A. T. Bahill, "Development, validation, and sensitivity analyses of human eye movement models", Crit. Rev. Bioeng., vol. 4, no. 4, pp. 311-352, Dec. 1980.

[3] O. Komogortsev et al., "2D linear oculomotor plant mathematical model", ACM Trans. Appl. Percept., 
vol. 10, no. 4, pp. 1-13, Oct. 2013. https ://doi.org/ $10.1145 / 2536764.2536774$

[4] M. C. Puell-Marín, "Óptica Fisiológica: El sistema óptico del ojo y la visión binocular", Madrid: Editorial Complutense, 2007.

[5] J. Perea, "Estrabismos", 2nd ed. Toledo: Artes Gráficas Toledo, S. A. U \& Laboratorios Alcon, 2008.

[6] M. C. Khoo, "Chapter 2: Mathematical Modeling", in Physiological Control Systems: Analysis, Simulation, and Estimation, Wiley-IEEE Press, 2000, pp. 20-22.

[7] X. Aguado-Jódar, I. Grande-Rodríguez and J. L. López-Elvira, "Consideraciones sobre conceptos y clasificaciones de la fuerza muscular desde el punto de vista mecánico", Universidad de Castilla la mancha, 1999 .

[8] A. Á. Valdivia, "Visión y trabajo (Guía de notas técnicas de prevención-NTP: 790)", Instituto nacional de seguridad e higiene en el trabajo, NIPO: 792-08-008-8, España, 2008. 